\title{
The Impact of Synchronous Online Learning on Students Attainment in Maths
}

\author{
Disa Evawani Lestari ${ }^{1}$, Purnama Dewi ${ }^{2}$ \\ ${ }^{1,2}$ President University, Jl. Ki Hajar Dewantara, Kota Jababeka, Cikarang Utara, West Java, Indonesia \\ disa.silaen@president.ac.id
}

\begin{abstract}
Due to the emergence of Covid-19 pandemic, many schools in Indonesia are implementing school from home where teachers and students have to learn from home, including the elementary school. Due to that fact, inevitably, teachers and students are challenged to do a synchronous online learning. Therefore, the aim of this research is to analyse the impact of synchronous online learning towards students' attainment in maths course. This research is used the triangulation method that can assist in confirming the set of findings based on the hypothesis. To serve that purpose, 16 students of Grade 4 of an elementary school in Jakarta were recruited as research participants. Data were collected from the students' maths final course score in term-1 (face to face) and term-2 (synchronous online learning), and participant observation result for 3 months long of in term-2 (synchronous online learning). Based on the analysis calculations using SPSS applications, the Paired Sample T-Test showed the sig. (2-tailed) of 0.014 , the result of 0.014 is below 0.05 , which means the synchronous online learning has caused significant decreased on students' attainment in maths courses compared to the face to face learning. The factor that can affect student attainment are students' readiness to use the technology and media, time management, physical and mental conditions of students on online learning and the focus of discussion.
\end{abstract}

Keywords: maths, student attainment, synchronous learning, face to face learning

\section{Abstrak}

Akibat munculnya pandemi Covid-19, banyak sekolah di Indonesia yang menerapkan sekolah dari rumah di mana guru dan siswa harus belajar dari rumah, termasuk di sekolah dasar. Berdasarkan fakta tersebut, tak pelak, guru dan siswa ditantang untuk melakukan pembelajaran daring sinkron. Oleh karena itu, tujuan dari penelitian ini adalah untuk menganalisis pengaruh pembelajaran online sinkron terhadap prestasi belajar matematika siswa. Penelitian ini menggunakan metode triangulasi yang dapat membantu dalam mengkonfirmasikan kumpulan temuan berdasarkan hipotesis. Untuk memenuhi tujuan tersebut, 16 siswa kelas 4 SD di Jakarta direkrut sebagai peserta penelitian. Data dikumpulkan dari nilai akhir mata pelajaran matematika siswa di semester-1 (tatap muka) dan semester-2 (pembelajaran online sinkron), serta hasil observasi peserta selama 3 bulan pada semester-2 (pembelajaran online sinkron). Berdasarkan perhitungan analisis menggunakan aplikasi SPSS, Paired Sample TTest menunjukkan nilai sig. (2-tailed) sebesar 0,014. Hasil 0,014 berada di bawah 0,05 yang berarti pembelajaran online sinkron telah menyebabkan penurunan yang signifikan pada hasil belajar matematika siswa dibandingkan dengan pembelajaran tatap muka. Faktor yang bisa mempengaruhi pencapaian siswa adalah kesiapan siswa dalam menggunakan teknologi dan media, manajemen waktu, kondisi fisik dan mental siswa terhadap pembelajaran online dan fokus diskusi.

Kata kunci: matematika, pencapaian siswa, pembelajaran sinkron, pembelajaran tatap muka

Copyright (c) 2021 Disa Evawani Lestari, Purnama Dewi

$\triangle$ Corresponding author: Disa Evawani Lestari

Email Address: disa.silaen@ president.ac.id (Jl. Ki Hajar Dewantara, Kota Jababeka, Cikarang Utara)

Received 11 Desember 2020, Accepted 07 March 2021, Published 09 April 2021

\section{INTRODUCTION}

Due to the emergence of Covid-19 pandemic, many schools in Indonesia are implementing school from home where teachers have to work from home, and students have to learn from home, including the elementary school. These decisions are made by considering the health and safety of students, teachers, school staff, and the community. Applying the learning from home, learning process can still be carried out without having face to face in class, and this will also support in preventing the spread of Covid-19 by carrying out social distancing (Kementrian Pendidikan dan Kebudayaan, 2020). 
Due to that fact, inevitably, teachers and students are challenged to move from face to face school activity to a synchronous online learning environment.

In implementing the synchronous online learning, teachers and students had to have abilities to operated digital devise. Therefore, school have to decide the materials used to support the learning process. Gambari, Yusuf, and Balogum (2015) also supports that the use of an appropriate technology can improve the learning achievement of the group have been teaching, and students can perceive a higher understanding of the ability of the material presented. However, Choi and Walters (2018) states if face to face discussion in the classroom highly recommended for students to get a more in-depth understanding of knowledge based on mathematics and science literature.

Based on the survey results conducted by UNICEF Indonesia on 18-29 May 2020 with more than 4,000 responses from students in 34 provinces, $66 \%$ students felt uncomfortable studying from home, $87 \%$ students wanted to learn to be done directly at school, $38 \%$ students lacked guidance from teachers, and 35\% cited that poor internet access affected their learning. Therefore, the active role and support of parents and teachers are vital for learners during the online learning process that occurs at home, whether it is synchronous or asynchronous online learning. As a result, the ultimate goal of each lesson for students will achieved both academically and actively in the learning process.

Online learning is a substitute method for face-to-face learning that usually occurs in schools, but this condition triggers concerns and questions both among students, teachers and parents. How the students perceives themselves honestly through the online learning experience is one among the most critical aspects of online education (Somenarain, Akkaraju, \& Gharbaran, 2010). Therefore, the support from the school community included parents to monitor the progress of each student in order to achieve the learning outcomes.

The face to face activity that occurs in school applies the learning goals such as in academic communication aspect, and others soft-skills part, which also needs to present in the online learning by using a different method and required more cooperatively with parents. As states by McGilvray (2014), the successful synchronous online learning requires students' readiness, such as operating digital devices, and their ability to absorb learning materials to support the learning process. Furthermore, students in elementary school might have difficulties when they trying to identify objects in an irregular form which they rarely found at home (Lowrie \& Logan, 2018). So that, teaching an elementary students level are required more concrete things and give directly explanation in learning maths which can be related to students reality daily activities.

There have been some studies that discuss and measure the successes of synchronous online learning. Kemp and Grieve (2014) states that synchronous online learning and face to face learning has no significant difference in terms of academic performance, such as the task and class material. The same result state by McKeever (2019), that the final grades of students were show equivalence between the online classes and face to face classes. Amry (2014) also mention that learning using technology or online learning has a positive impact on student attainment. However, the participant involve in that 
research are not elementary school level. It is assumed that, when the participant is different the result may also be different.

The research found by among the researchers above is involved adults learners participants. According to that, this research involved different level of participant and in line with the maths subject. Therefore, this research is designed to compare students' attainment in the face to face learning and synchronous online learning as well as to explore the factors that affect students' attainment on that issue in online environment.

\section{METHOD}

This research is used the triangulation method that can assist in confirming the set of findings based on the hypothesis (Noble \& Heale, 2019). The triangulation data is collected using the mixing method to ensure in-depth set of findings, including both, quantitative and qualitative data sources, data triangulation assumed by using various sources of data within an organization (Stojanov, 2016). To collect the quantitative data, it is usually obtain from an available document from an organisation. Quantitative data can give evidence for the research, so the researcher can consider the result that supports the objectives (Fryer, Larson-Hall, \& Stewart, 2018).

According to Queirós, Faria, and Almeida (2017), quantitative focuses on the appropriate objectivity that possible to collecting the variables and inferences from samples of a population. Qualitative data can be taken from an individual or in-depth group perspective through observations, using a structured interview, or spread out the questionnaire. Qualitative data can provide the researcher to obtain the depth of understanding as to the support reason related to the result (Palinkas et al., 2013).

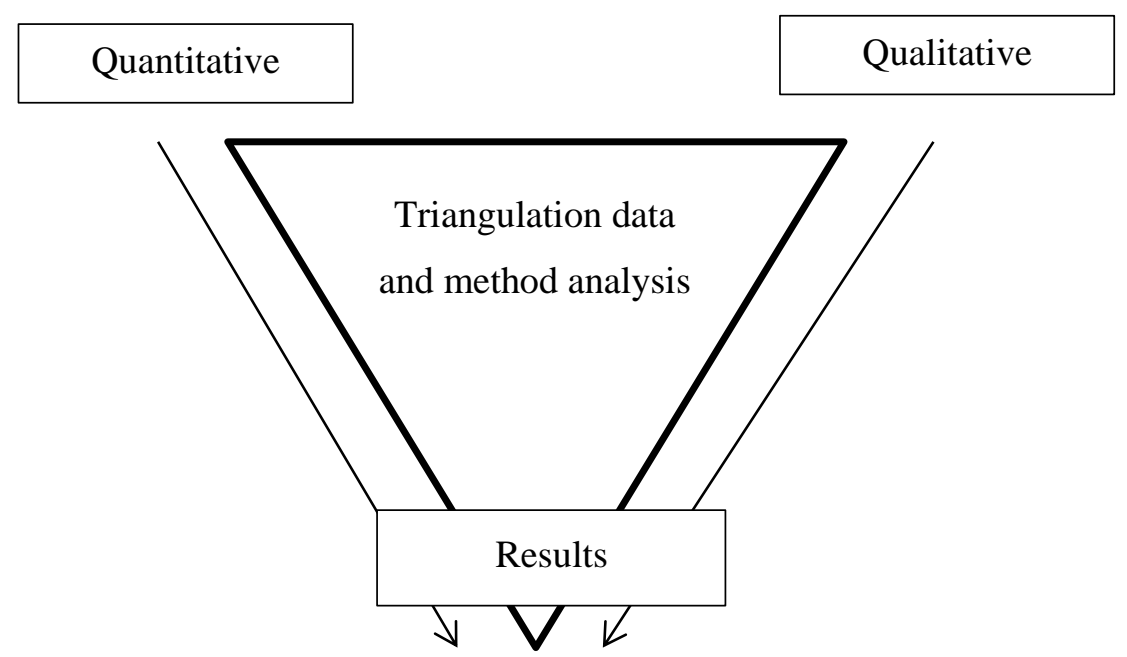

Figure 1.Triangulation data and method analysis in synchronous online learning

This research will involve one private elementary school in Jakarta. The participants involved in this research will be 16 students of grade four that enrolled in synchronous online learning on that school. Of those 16 students $2(12,5 \%)$ students are male and $14(87,5 \%)$ students are female. The students and teachers are living in the city, which is near the school. However, due to Covid-19 pandemic, 
students and teachers stay in different regions because the learning conducted by online. The online learning process is using Zoom applications for live-streamed lectures; also e-mail and Google Classroom to distribute the learning materials and submitting assignments.

To collect the data for this research, the maths course final score from term- 1 and term- 2 is collected through the face to face learning activities and the online learning activities through livestreamed lectures method. The data which used in this research are divided into two:

1. The students' maths final course score from term-1 until term-2 school year.

2. Participant observation result form 3 months long of synchronous online learning to support the quantitative data (participant observation data will be gain by pay attention at the interactions that occurring in the setting).

The quantitative data obtained will be analysed and will processed through SPSS Version 22.0 (Statistical Package for the Social Sciences) software to calculate the values of a specific. This converted value subsequently used to draw conclusions and validate the hypothesis. The final grade variable that identified a maths course in grade 4 has two possible values between face-to-face and online, which are useful or ineffective. The both data will be analyse using Paired Sample T-Test to know whether the there is a statistical evidence of difference between the data. The result of sig. (2tailed) has to be equal to 0.05 or smaller than 0.05 to declare if the result is significant, yet if the result showed the opposite, it means not significant.

The qualitative data from the observation will be analysed using thematic analysis to explore the available hypothesis related to this research. In data analysis process will be carry out in the form of text as proxy for experience analysis from my interaction with the research participant (Guest, MacQueen, \& Namey, 2011). Furthermore, the conclusion will draw from the data obtained. The process of gained the data obtain is from participant observation notes.

\section{RESULT AND DISCUSSION}

\section{Result}

Final maths course grade for the term- 1 and term- 2 school year represented one of the primary outcome variables for this research, by estimated the mean of students' maths final course score from term-1 until term-2. The mean were critical aspect to compare the math performance during face to face learning at school and synchronous online learning. Figure 2 shows us the data of maths final score of each student. These end-of-course grades were measure on the scale of 0 to 100 . The evidence of maths performance was measure from multiple sources of taught lesson topic to get the total score. Term-1 they learned about four operation, decimals, whole number, and symmetry and at term- 2 they learned about geometry, factors, fraction, number and place value, and graph. The assessments, as mentioned earlier, were valid and relevant, which they were useful in gauging students' ability and generating the objective performance measurements by the students. According to that students who gets A, B, C, and $\mathrm{D}$ on term- 1 is $\mathrm{A}>24 \%, \mathrm{~B}>49 \%, \mathrm{C}<20 \%$, and $\mathrm{D}<7 \%$, and on term- 2 as $\mathrm{A}<7 \%, \mathrm{~B}>55 \%, \mathrm{C}>$ 
$31 \%$, and $\mathrm{D}<7 \%$ of students.

Table 1. Students' maths final score at term-1 and term-2

\begin{tabular}{|c|c|c|}
\hline Students & Term-1 & Term-2 \\
\hline $\mathbf{1}$ & 92.96 & 88.74 \\
\hline $\mathbf{2}$ & 87.44 & 70.86 \\
\hline $\mathbf{3}$ & 49.75 & 49.01 \\
\hline $\mathbf{4}$ & 88.44 & 76.16 \\
\hline $\mathbf{5}$ & 79.90 & 80.79 \\
\hline $\mathbf{6}$ & 79.40 & 56.95 \\
\hline $\mathbf{7}$ & 90.95 & 82.78 \\
\hline $\mathbf{8}$ & 94.97 & 81.46 \\
\hline $\mathbf{9}$ & 54.27 & 50.33 \\
\hline $\mathbf{1 0}$ & 96.48 & 78.81 \\
\hline $\mathbf{1 1}$ & 82.41 & 84.11 \\
\hline $\mathbf{1 2}$ & 75.88 & 60.93 \\
\hline $\mathbf{1 3}$ & 59.80 & 60.93 \\
\hline $\mathbf{1 4}$ & 74.87 & 71.52 \\
\hline $\mathbf{1 5}$ & 84.92 & 90.73 \\
\hline $\mathbf{1 6}$ & 50.75 & 58.28 \\
\hline
\end{tabular}

To observe the pattern that whether the students' attainments are increased or decreased, the data is presented by using the scale scores graph. Figure 2 showed that students' final score in maths in term- 1 and term- 2 are unstable and it can be concluded if there was a decreased score on maths course. According to the scale we cannot predict that the synchronous online learning has given an impact in accordance with students' appointment in learning maths.

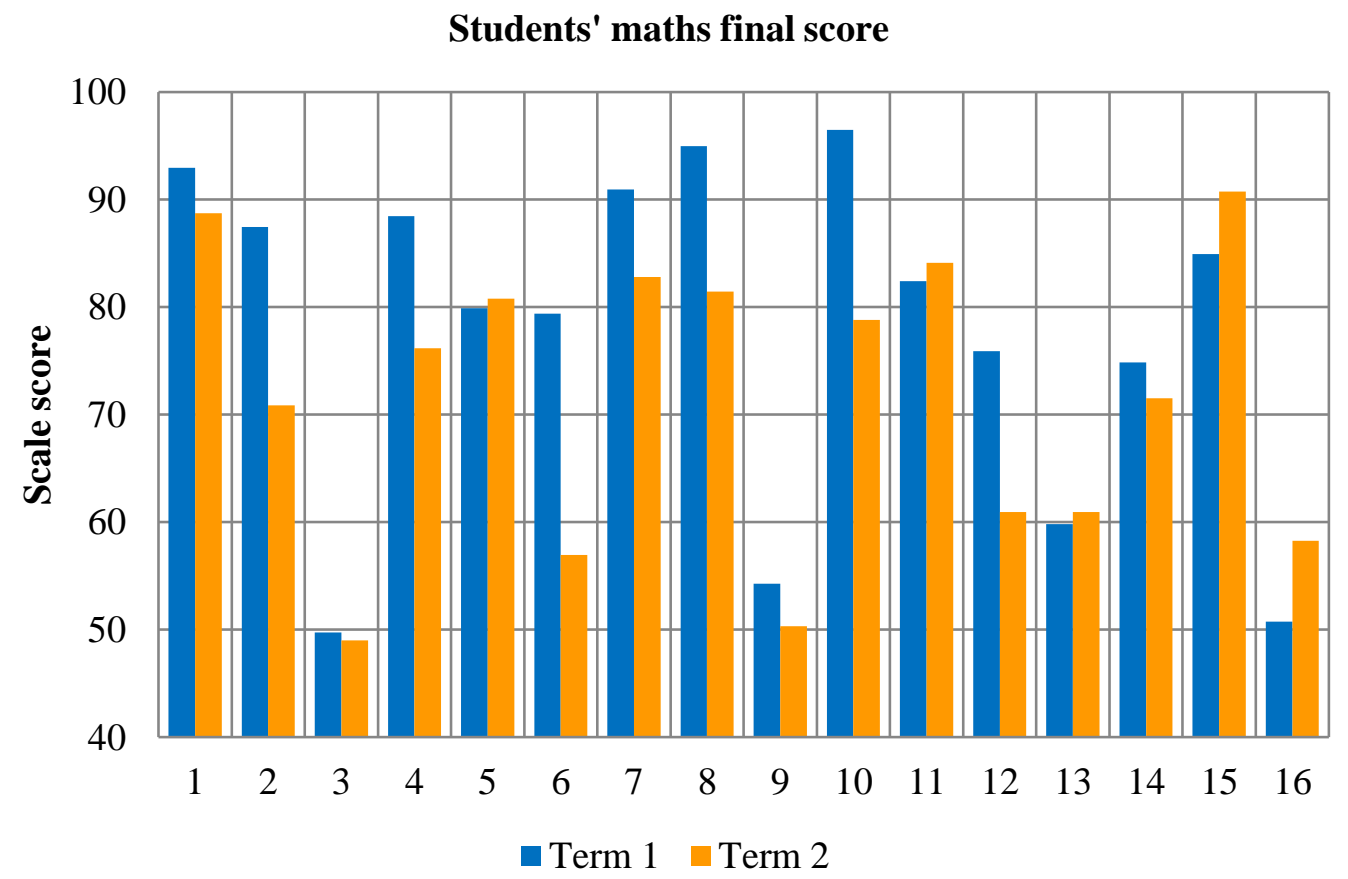

Figure 2. Students final score in scale 40-100 
From Figure 2, only showed the ups and down scale on the bar chart colour, where the blue colour (term-1) looks more prominent than the yellow colour (term-2). Therefore, to find the sufficient evidence the synchronous online learning has a significant impact on the students' maths final course score we need to validate maths final course of both learning style using SPSS application.

\begin{tabular}{|l|c|c|c|c|c|}
\hline & $\mathrm{N}$ & Minimum & Maximum & Mean & Std. Deviation \\
\hline Term_1 & 16 & 49.75 & 96.48 & 77.6994 & 15.78993 \\
Term_2 & 16 & 49.01 & 90.73 & 71.3994 & 13.60896 \\
\hline Valid N & 16 & & & & \\
(listwise) & 16 & & & & \\
\hline
\end{tabular}

Figure 3. Descriptive Statistics Result

Based on the table shown above, we know the number of students on term- 1 and term- 2 is 16 students. The average or mean value for term- 1 is 77.6994 and term- 2 is 71.3994 . According to the mean result of students' maths learning outcomes, it can be concluded that there are changes from term-1to term-2. However, is the difference significant enough? To know if the result shown on Figure 3 is significant or not significant, Paired Sample T-Test is used to analyse.

Paired Samples Statistics

\begin{tabular}{|ll|c|c|c|c|}
\hline & & Mean & N & Std. Deviation & Std. Error Mean \\
\hline Pair 1 & Term_3 & 77.6994 & 16 & 15.78993 & 3.94748 \\
& Term_4 & 71.3994 & 16 & 13.60896 & 3.40224 \\
\hline
\end{tabular}

Paired Samples Correlations

\begin{tabular}{|ll|c|c|c|}
\hline & $\mathrm{N}$ & Correlation & Sig. \\
\hline Pair 1 & Term_3 \& Term_4 & 16 & .822 & .000 \\
\hline
\end{tabular}

\begin{tabular}{|c|c|c|c|c|c|c|c|c|}
\hline & \multicolumn{5}{|c|}{ Paired Differences } & \multirow[b]{3}{*}{$\mathrm{t}$} & \multirow[b]{3}{*}{$\mathrm{df}$} & \multirow{3}{*}{$\begin{array}{c}\text { Sig. } \\
(2- \\
\text { tailed } \\
)\end{array}$} \\
\hline & \multirow[b]{2}{*}{ Mean } & \multirow{2}{*}{$\begin{array}{c}\text { Std. } \\
\text { Deviation }\end{array}$} & \multirow{2}{*}{$\begin{array}{l}\text { Std. } \\
\text { Error } \\
\text { Mean }\end{array}$} & \multicolumn{2}{|c|}{$\begin{array}{l}95 \% \text { Confidence } \\
\text { Interval of the } \\
\text { Difference }\end{array}$} & & & \\
\hline & & & & Lower & Upper & & & \\
\hline $\begin{array}{c}\text { Pair } \\
\text { Term_1 } \\
\text { Term_2 }\end{array}$ & 6.30000 & 9.01915 & 2.25479 & 1.49403 & 11.10597 & 2.794 & 15 & .014 \\
\hline
\end{tabular}

Figure 4. Paired Samples T-Test Result

The Paired Sample Statistic repeated the outputs of Figure 4, in which the average or mean value for term-1 is 77.6994 and term-2 is 71.3994. The Paired Sample Correlations tables is add information 
that maths final score in term- 1 and term- 2 are significantly positively correlated with the value of $r=$ 0,822. Furthermore on the 'Paired Sample Test' table, in the sig (2-tailed) column it shows that the value is 0.014 , where the value is less than 0.05 (5\%). Therefore, it can be concluded that there is a significant difference between students' maths final score in the learning outcomes of face to face learning (term1) and synchronous online learning (term-2).

Related to the result above, the explored factor based on the participant observation shows students' enthusiasm in learning, and they seem to enjoy online learning. In the beginning, teachers at the school carried out the live-streamed lectures method and discussion using Zoom, and they always started the lesson with some games such as riddles to refresh their minds in the first 15 minutes. The maths course is usually running over 40 minutes until 80 minutes for each day. Moreover, not uncommonly for the teacher to place some courses not according to the existing schedule to cover topics that are not finish to explain yet.

The class also enforced regulations that students need to obey, such as students must turn on their camera, mute the microphone while the learning occurs, raise their hand to ask the question, and the microphone can be unmuted if the teacher asked the students. Indeed, those regulations are applied to preventing parents' intervention who would provide answers and helped their children to do the assignment or quiz given by the teacher. However, when students were enthusiastic about learning, they often spoke at the same time when they wanted to share their thoughts, and the classroom situation became less conducive.

In term-1, the teacher would prepare the instructional materials such as printed learning exercises and learning videos to download or stream during the class before the Covid-19 pandemic. With the implementation of synchronous online learning in term-2, it is undeniable that learning becomes faster where media is accessible to access by teachers, and students can easily access it too. Besides using a video, the teacher used e-mail and Google Classroom for delivering and submitting learning material. This instructional strategy is in line with the media that used at the school has practiced and taught it to the students and socialized to most parents. Contributions from parents are also much appreciated by providing the children tools to attend the synchronous online learning. Parents were very supportive by always cheering the teachers and their children while learning occurred.

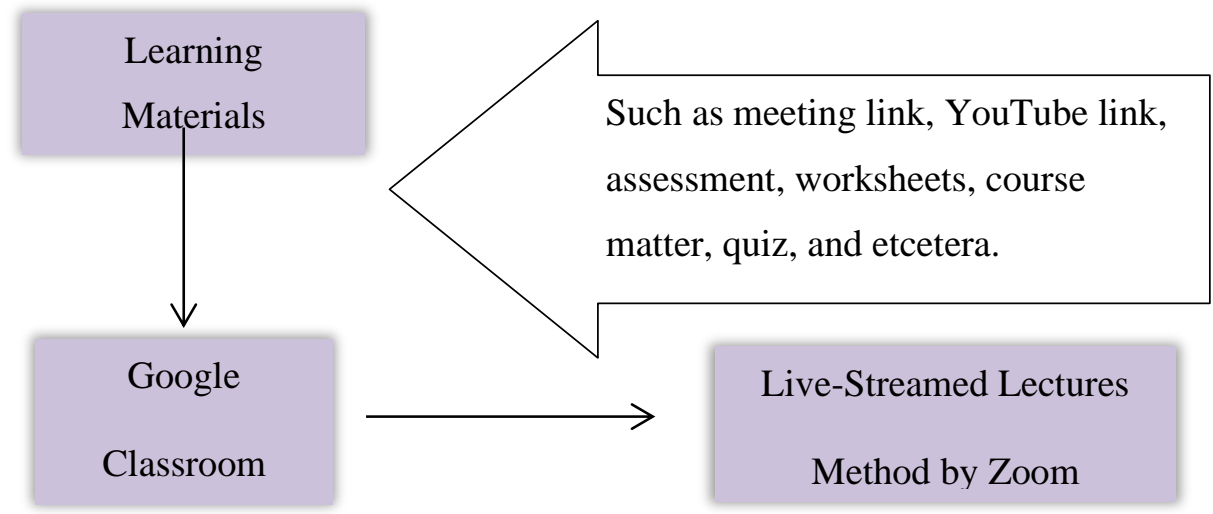

Figure 5. Instructional strategies on synchronous online learning 
Meanwhile, when the learning process came to the middle of the lesson, some students rubbed their eyes and felt bored during the class, especially in maths. Students sometimes express their overwhelmed feeling when they have to prepare the learning materials where they have to write or print their materials, especially in maths. Those expressions include use his hand to support his head, played with their swivel chair, and yawn. Students also might be left behind from the explanation given because of the internet problem. Not only the students, teachers sometimes need to repeat the explanations twice or even more due to time constraints and other problems such as low internet signals, and the condition of online classrooms that are less conducive to learning.

Additionally, there are exciting things that emerged during online learning. In the view of students' activeness and their interaction in the discussion, online learning makes students who are initially passive in face-to-face learning more daring to speak and express themselves, especially in English and social topics. However, when viewed from the maths lesson evaluation the results were different.

\section{Discussion}

The Covid-19 pandemic has significantly affected all countries in all around the world, without any exceptions to Indonesia. Due to the increased number of people exposed to the Covid-19 virus, the school from home must be implemented to avoid the virus. School from the home system has a varied option, such as using the online application; make short video learning explanations, preparing the learning package, or modules. The school in this research implemented synchronous online learning, and the purpose of this research is to compare students' attainment in face-to-face learning and synchronous online learning.

This research showed a significant difference in students' performance between the face-to-face learning and synchronous online learning by concerning the final score in learning maths. Based on the result, it can be said that the implemented of synchronous online learning has cause significant decreased on students' attainment in maths courses compared to the face to face learning. In other words, the result expresses that the synchronous online learning applied in the school are ineffective compare to face to face learning. This is in line with the study conducted by Loeb (2020) that in comparison to faceto-face learning and online learning, online classes are not as practical as face-to-face classes for most elementary school students.

Therefore, it can be said that synchronous online learning is not fully adequate for elementary school students. Accompanied by the changes from face-to-face learning style to synchronous online learning, there may be many factors that can decrease student performance. The factors that can create those barriers might be from the internal aspects or external aspects. Hart (2012) also mention that factors such as satisfaction with online learning, a sense of belonging to the learning community, motivation, peer, family support, time management skills, and communication with the instructor are associated with student persistence in online learning.

Internal factors such as self-efficacy of students' readiness are critical matters that can quickly 
affect the learning process. To apply synchronous online learning, the student must prepare themselves in skills, mentally and physically. In the class observed, the students are well-prepared to use the technology and media during the online learning, yet they seem not well-prepared in time management such as did not prepare the materials that need to be printed, whereas the materials had been provided one day before the class. Therefore, students have to prepare for materials when going to enter a certain learning courses time. In line with that, time management and technical skills regarding technology selfefficacy are can affect the online learning outcomes (Kauffman, 2015). Students' readiness aspects would make online learning more accessible for students to take part in the learning process.

However, students' initial readiness is not the only factor, but how students act and respond to the online learning that occurs is also the critical factor of successful online learning. Students have to interact with the learning process when they were in online learning, yet the critical aspect is the amount of interaction and the quality of interaction matters (Dhilla, 2017). Hence, there have to be interactions related to the topic lesson being discussed during the online class. Hoang, Naderi, Cheng, \& Aryana (2019) also states that the focus of topic discussion could categorize as external barriers as it can bring up other concerns and challenges of technology used in online learning. When the online learning occurs, commonly students interested to talk about their personal topics outside the learning courses. Those personal topics include their activities at home; talk about their pets, and sometimes about their family's activities.

Croxton (2014) mention that the right balance of interaction occurred is critical to both student satisfaction and online class completion because it plays an essential role in online learning quality. Muzammil, Sutawijaya, and Harsasi (2019) also supports that interaction has had a positive impact on student engagement, and students' interaction also positively correlated to the learning effectiveness of online learning based courses. Meanwhile in the class observed, interaction between teacher and students or student and student are not fully balanced. The interaction occurred between teacher and students are usually lack in giving a fair response, while between student and student commonly unbalanced in group discussion where the passive students does not really take a role over in decision making.

Along with that, students' participation in synchronous online learning needs to be boosted, as they seem to have lost interest in overtime during the online class occurred. Therefore, teachers must be creative and also innovative at the same time in designing teaching instructional strategies include teaching method, media, and online learning stuff used, so the learning objectives can be achieved. In addition, to support the quality of learning during the synchronous online learning period, it lies not only in the teacher's role but also in the contributions of all members of the school community.

To encourage more enthusiastic participation of students in online learning, the use of varied instructional methods will significantly help the teachers to encourage more enthusiastic participation in online learning. However, sometimes the feedback given took a lot of time in the learning process and it makes students have to facing the screen. Alternatively, the feedback which given during the 
online learning can be change into students self-reflection and teacher can give additional information in another meeting as it needed. As Coogle and Floyd (2015) mentions that the teacher can provide additional time for students to reflect their self, so they do not have to facing the computer screen for a long time. It is the challenges that teachers and students have to face, yet to minimize the screen time, the evaluation or feedback needed are can be given through email or might be given on the next day as a review of the previous lessons.

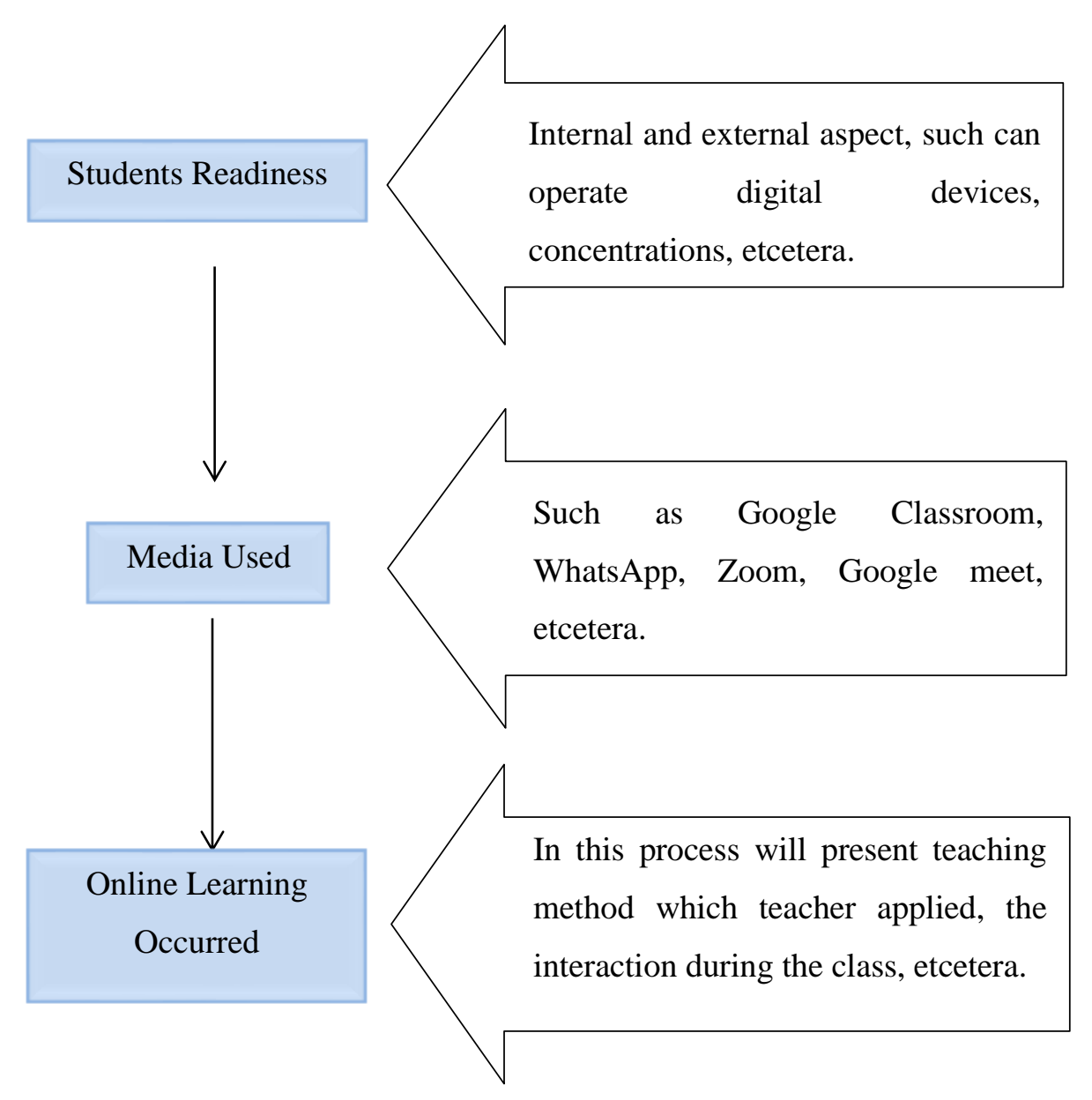

Figure 6. Instructional Learning Process

\section{CONCLUSION}

The results of this research showed that the synchronous online learning is not as effective as face to face to face learning based on the maths final score comparison on both learning style. Through analysis calculations using SPSS applications, the Paired Sample T-Test showed the sig. (2-tailed) of 0.014. Based on that, the result of 0.014 is below 0.05 , which means the synchronous online learning has cause significant decreased on students' attainment in maths courses compared to the face to face learning.

Participant observation method used involves the researcher's involvement in a face to face and synchronous online learning activity with an extended period of time to observe their daily class routines and to participate in their activities to facilitate the research. The data collection process involves 
entering into a school, participating in many different activities allowed by community members and taking regular notes to facilitate narrative development to explore the factors that affect students' attainment on synchronous online learning.

According to the findings of this research, factors that affect students' attainment in learning maths came from two aspects, which are internal and external. The internal aspects include students' readiness such as well-prepared to use the technology and media, time management, physical and mental conditions in accordance to students' response on online learning. The interaction among the students might barrier the focus of discussion that includes the external factors.

Based on the research result, the next researcher can utilise a broader population and longer time period, as well as a wider scope of instructional focus to compliment these findings that covered a limited area of maths course lesson in synchronous online learning. With utilising broader population, researchers can involving more students, teachers, and online courses related to achieve better evaluate of benefits, challenges, and useful strategies used in class. Future researcher can found a study of this maths by comparing online learning and face to face learning with explore various factors such students' motivations, and their satisfactions in learn maths.

To explore more about the implemented of online learning at schools would need to add information which obtain from the students perspectives such as their satisfactions feeling, types of course subject that students interest more, etcetera. In addition, reading a study with multi-time measurements would be helpful in understanding the dynamics among students' cognitive processes and students' readiness throughout the term/semester. Future research also could address perceptions of the parents and teachers about the implementation of synchronous online learning. For the student audience in the research population, the researchers could be better if he can jump in the real part-time performed in both face to face and online courses as comparisons.

In addition, by applying the participant observation in this research, it was potentially courses to a new factors bias for the online lesson, yet it was only personal perceptions. To further expand the findings of this research, future research could input more empirical evidence on students' perceptions to use in looking into possible correlation between the different learning styles.

\section{ACKNOWLEDGEMENT}

I would like to thank my parents and my whole family, and my friends Tyas, Karin, Mike, and Chika who somehow manage to be nothing but supportive of this research. Personally, for all lecturer who have taught me during my time in President University, Ms. Ani, Ms. Disa, Mr. Richard, Mr. Donald, Ms. Grace, Ms. Risa, Mr. Tria, Prof. Nena, Prof. Slameto, and Ms. Jani. Last but not least, for everyone under the auspices of the Primary School Teacher Education study program and everyone who helped me during the time. 


\section{REFENRENCES}

Amry, A., B. (2014). The impact of whatsapp mobile social learning on the achievement and attitudes of female students compared with face to face learning in the classroom. European Scientific Journal, 20(22), 116-136.

Choi, J., \& Walters, A. (2018). Exploring the impact of small-group synchronous discourse sessions in online math learning. Online Learning, 22(4), 47-64. https://doi.org/10.24059/olj.v22i4.1511

Coogle, C., \& Floyd, K. (2015). Synchronous and asynchronous learning environments of rural graduate early childhood special educators utilizing Wimba $\odot$ and Ecampus. MERLOT Journal of Online Learning and Teaching, 11(2).

Croxton, R. A. (2014). The role of interactivity in student satisfaction and persistence in online learning. Journal of Online Learning and Teaching, 10 (2), 314.

Dhilla, S. J. (2017). The role of online faculty in supporting successful online learning enterprises: A literature review. Higher Education Politics \& Economics, 3(1), 3.

Fryer, L. K., Larson-Hall, J., \& Stewart, J. (2018). Quantitative methodology. The Palgrave Handbook of Applied Linguistics Research Methodology,55-77. https://doi.org/10.1057/978-1-137-59900-1_3

Gambari, A. I., Yusuf, H. T., \& Balogun, S. A. (2015). Effectiveness of PowerPoint presentation on students' sognitive schievement in technical drawing. Malaysian Online Journal of Educational Technology, 3(4), 1-12.

Guest, G., MacQueen, K. M., \& Namey, E. E. (2011). Applied thematic analysis. SAGE Publications, Inc.

Hart, C. (2012). Factors associated with student persistence in an online program of study: A review of the literature. Journal of Interactive Online Learning, 11(1).

Hoang, D., Naderi, E., Cheng, R., Aryana, B. (2019). Adopting immersive technologies for design practice: the internal and external barriers. International Conference on Engineering Design (ICED19), Delft. https://doi.org/10.1017/dsi.2019.196

Kauffman, H. (2015). A review of predictive factors of student success in and satisfaction with online learning. Research in Learning Technology, 23. https://doi.org/10.3402/rlt.v23.26507

Kementrian Pendidikan dan Kebudayaan. (2020, March 26). Kemendikbud bekerja sama dengan operator telekomunikasi sukseskan pembelajaran di rumah. https://www.kemdikbud.go.id /main/blog/2020/03/kemendikbud-bekerja-sama-dengan-operator-telekomunikasi-sukseskanpembelajaran-di-rumah

Kemp, N., \& Grieve, R. (2014). Face-to-face or face-to-screen? Undergraduates' opinions and test performance in classroom vs. online learning. Frontiers in psychology, 5, 1278, 1-11. https://doi.org/10.3389/fpsyg.2014.01278 
Loeb, S. (March, 2020). How effective is online learning? what the research does and doesn't tell us. https://www.edweek.org/ew/articles/2020/03/23/howeffective-is-online-learningwhatthe.html

Lowrie, T., \& Logan, T. (2018). The interaction between spatial reasoning constructs and mathematics understandings in elementary classrooms. Research in Mathematics Education, 253-276. https://doi.org/10.1007/978-3-319-98767-5_12

Noble, H., \& Heale, R. (2019). Triangulation in research, with examples. Evidence Based Nursing, 22(3), 67-68. https://doi.org/10.1136/ebnurs-2019-103145

McGilvray, K. C. (2014). An analysis of student preparedness factors that aid in satisfaction and retention in online courses and programs [Doctoral dissertation, University of Toledo]. ETD OhioLink. https://etd.ohiolink.edu/rws_etd/send_file/send?accession=toledo1396452179\&disp osition=inline

McKeever, B., W. (2019). Different formats, equal outcomes? comparing in-person and online education in public relations. Journal of Public Relations Education, 5 (2), 1-40.

Muzammil, M., Sutawijaya, A., \& Harsasi, M. (2019). Student satisfaction in online learning: can student engagement becomes driving factor based on student interaction?. International Open \& Distance Learning Conference,91-97.

Palinkas, L. A., Horwitz, S. M., Green, C. A., Wisdom, J. P., Duan, N., \& Hoagwood, K. (2013). Purposeful sampling for qualitative data collection and analysis in mixed method implementation research. Administration and Policy in Mental Health and Mental Health Services Research, 42(5), 533-544. https://doi.org/10.1007/s10488-013-0528-y

Queirós, A., Faria, D., \& Almeida, F. (2017). Strengths and limitations of qualitative and quantitative research methods. European Journal of Education Studie, 3(9), 369-387. https://doi.org/10.5281/zenodo.887089

Somenarain, L., Akkaraju, S., \& Gharbaran, R. (2010). Student perceptions and learning outcomes in asynchronous and synchronous online learning environment in a Biology course. MERLOT Journal of Online Learning and Teaching, 3(2), 353-356.

Stojanov, Z. (2016). Inductive approaches in software process assessment. International Conference on Applied Internet and Information Technologies. https://doi.org/10.20544/AIIT2016.I01

UNICEF Indonesia. (2020, June 16). Indonesia: Survei terbaru menunjukkan bagaimana siswa belajar dari rumah. https://www.unicef.org/indonesia/id/press-releases/indonesia-surveiterbaru-menunjukkan-bagaimana-siswa-belajar-dari-rumah 